\title{
Evaluation of qualitative characteristics of Bali cattle at Bali breeding center
}

\author{
Rosidi Azis ${ }^{1}$, Veronica Margareta Ani Nurgiartiningsih ${ }^{2 *}$, Sri Wahjuningsih ${ }^{2}$, Herni \\ Sudarwati ${ }^{2}$, and Ahmad Furqon ${ }^{2}$ \\ ${ }^{1}$ Animal Science Doctoral Program, Faculty of Animal Science, University Brawijaya, Malang \\ 65145, East Java, Indonesia \\ ${ }^{2}$ Faculty of Animal Science, University Brawijaya, Malang 65145, East Java, Indonesia
}

\begin{abstract}
The aim of this study was to identify the qualitative characteristics of Bali cattle at Bali Breeding Center. The samples used were 136 heads. Qualitative data was analysed based on the percentage for each trait and analyzed descriptively. The results showed that the characteristic with the highest percentage were brick red for females of Bali cattle $(84,81 \%)$, black for males Bali cattle $(86.66 \%)$, dominant thick back line $(79.74 \%)$ for females, while on males was not clear $(86,67 \%)$, strict line of body color border with leg $(100 \%$ for males and $91,14 \%$ for females), strict line of body color border with buttocks color $(93,33 \%$ for males and $88,61 \%$ for females), white of edge lips color $(95 \%$ for males and $93,67 \%$ for females), black eyelid color (100\%), white ear hair color (males: $100 \%$ \& females: $96,20 \%$ ), dark circles on the ears $(98.73 \%)$, dominant medium wattle for males $(93,33 \%) \&$ small wattle for females $(53,16 \%)$, upwards horn (males: $100 \%$ \& females: $94.93 \%$ ), black tail feathers (males: $100 \%$ \& females: $98.04 \%$ ), and no hump (males: $96.66 \%$ \& females: $100 \%$ ). The qualitative characteristics of Bali cattle at Bali breeding center were in line with Indonesian National Standard. However, there were deviations and abnormality with a small percentage.
\end{abstract}

\section{Introduction}

One of the diversities of Indonesian livestock genetic resources is Bali cattle as beefproducer. Bali cattle are native Indonesian cattle that contribute to the fulfillment of meat in Indonesia. Bali cattle are spread in several areas in Indonesia such as West Nusa Tenggara, East Nusa Tenggara and Sulawesi [1,2]. The distribution of Bali cattle has been widespread in tropical and subtropical environments outside of Indonesia before its distribution was limited. Throughout the wide distribution of Bali cattle, there were no significant problems in terms of reproductive function so that Bali cattle grow and develop as in their native area [3]. The high adaptability of production and reproduction despite being in a marginal environment has made Bali cattle much in demand today [3-5]. However, the genetic potential of Bali cattle developed outside Bali is not the same as that in Bali.

\footnotetext{
*Corresponding author: vm_ani@ub.ac.id
} 
The qualitative characteristics of female Bali cattle are brick red, but the bull is black, the back of the thigh is white, the edges of the upper lip and the thigh of the lower leg start from the tarsus and carpus to the upper edge of the hoof, fur on the tip the tail is black, the fur on the ears is white and on the top of the back there is a black line [6,7]. The most easily identifiable characteristic of Bali cattle is brick red, but at the age of 12-18 months, bulls change color from brick red to black [8].

Qualitative properties are less valuable than quantitative traits [6], but in certain circumstances have high economic value. Qualitative nature becomes important at the time of traditional and religious events. Complete information on the qualitative characteristics of Bali cattle is still limited. This study aims to identify qualitative characteristics such as coat color, horns and other specific qualitative characteristics of Bali cattle. This is done as an effort to evaluate the qualitative characteristics of Bali cattle at the Bali Breeding Center.

\section{Materials and methods}

The total sample was 139 Bali cattle consisting of 79 females and 60 males with the criteria of 2-5 years of age at the Bali breeding center. Qualitative characteristics include the presence of dominant skin color (dominant color in female cattle: brick red, light brown, yellowish brown, spotted; while bulls: dark brown, black, reddish black), body color border with the buttocks, body color border with the back. legs, tail feathers, black eye circles, black lines on the back, the direction of the horns, the presence or absence of wattles and the presence or absence of a hump.

Qualitative trait data were analyzed descriptively with frequency calculated and displayed in percentage form for each trait using the following formula:

$$
P(x)=\frac{\sum X i}{n} \times 100 \%
$$

P : Percentage of colors that appear

$\mathrm{xi}$ : the property being measured

$\mathrm{n}$ : total sample

\section{Results and discussion}

The results of observations of the qualitative characteristics of bull and cow Bali cattle at the Bali Breeding Center are as shown in Table 1 and 2. Based on the two Table, Bali cattle at Bali Breeding Center have dominant black color $(86,67 \%)$ of males and brick red $(84,81 \%)$ of females. The thick back lines on females was clear $(79,75 \%)$, while on males was not clear $(86,67 \%)$. The body color border with legs have dominan strict lines (males = $100 \%$ and females $=91,14 \%$ ), as well as the body color border with the buttocks have dominan strict lines (males $=93,33 \%$ and females $=88,61 \%$ ). The white color on the edges of the lips was both dominant (males $=95,00 \%$ and females $=93,67 \%$ ). The eyelid color was black dominant $(100 \%)$, ear hair color dominant white on males and females, black ring on dominant ear black, dominant moderate and small wattle, dominant horn direction upwards, dominant black tail feathers and no dominant hump. Characteristics of qualitative properties obtained in previous studies [9-11]. These characteristics have the appearance of similar character to Banteng, but the body of Bali cattle was smaller than Banteng [12]. The phenotypic similarity between Bali cattle and Banteng was evidence that the relationship between Bali cattle and Banteng have similar qualitative characteristics [13, $14]$ 
Table 1. Qualitative characteristics male Bali cattle at Bali breeding center

\begin{tabular}{|c|c|c|c|}
\hline Qualitative Characteristic & $\mathbf{n}$ & Character & $\begin{array}{c}\text { Percentage } \\
(\%)\end{array}$ \\
\hline \multirow[t]{3}{*}{ dominant skin color } & 7 & Dark brown & 11,67 \\
\hline & 52 & Black & 86,67 \\
\hline & 1 & Reddish black & 1,66 \\
\hline \multirow[t]{4}{*}{ Back line } & 0 & Thick & 0 \\
\hline & 1 & Medium & 1,67 \\
\hline & 7 & Thin & 11,67 \\
\hline & 52 & Not clear & 86,67 \\
\hline \multirow[t]{3}{*}{ Body color border with legs } & 60 & Strict lines & 100 \\
\hline & & Gradation (no clear) & 0 \\
\hline & & No border & 0 \\
\hline \multirow[t]{3}{*}{ Body color border with buttocks } & 56 & Strict lines & 93,33 \\
\hline & 4 & Gradation (no clear) & 6,67 \\
\hline & & No border & 0 \\
\hline \multirow[t]{2}{*}{ Lip edge color } & 57 & White on the edge & 95,00 \\
\hline & 3 & White circle & 5,00 \\
\hline \multirow[t]{2}{*}{ Eyelids color } & 60 & Black & 100 \\
\hline & & Kedness & 0 \\
\hline \multirow[t]{3}{*}{ Ear hair color } & 60 & White & 96,67 \\
\hline & & Brown & 3,33 \\
\hline & & Black & 0 \\
\hline \multirow[t]{2}{*}{ Ear black circle } & & Black & 0 \\
\hline & 4 & No black circle & 1,67 \\
\hline \multirow[t]{3}{*}{ Wattle } & 1 & Long & 1,67 \\
\hline & 56 & Medium & 93,33 \\
\hline & 3 & Small & 5,00 \\
\hline \multirow[t]{3}{*}{ Horn } & & Forward & 0 \\
\hline & 60 & Upward & 100 \\
\hline & & backwards & 0 \\
\hline \multirow[t]{2}{*}{ Tail hair } & 60 & Black & 100 \\
\hline & & White/panjut & 0 \\
\hline \multirow[t]{2}{*}{ Hump } & 2 & Yes & 3,33 \\
\hline & 58 & No & 96,67 \\
\hline
\end{tabular}


Table 2. Qualitative characteristics female Bali cattle at Bali breeding center

\begin{tabular}{|c|c|c|c|}
\hline Qualitative Characteristic & $\mathbf{n}$ & Character & $\begin{array}{l}\text { Percentage } \\
(\%)\end{array}$ \\
\hline \multirow[t]{4}{*}{ Dominant skin color } & 67 & Brick red & 84,81 \\
\hline & 7 & Light brown & 8,86 \\
\hline & 3 & Yellowish-brown & 3,79 \\
\hline & 2 & Spotted & 2,53 \\
\hline \multirow[t]{4}{*}{ Back line } & 63 & Thick & 79,75 \\
\hline & 9 & Medium & 11,39 \\
\hline & 7 & Thin & 8,86 \\
\hline & 2 & Not clear & 2,53 \\
\hline \multirow[t]{3}{*}{ Body color border with legs } & 72 & Strict lines & 91,14 \\
\hline & 7 & Gradation (no clear) & 8,86 \\
\hline & & No border & 0 \\
\hline \multirow[t]{3}{*}{ Body color border with buttocks } & 70 & Strict lines & 88,61 \\
\hline & 9 & Gradation (no clear) & 10,13 \\
\hline & & No border & 1,26 \\
\hline \multirow[t]{2}{*}{ Lip edge color } & 74 & White on the edge & 93,67 \\
\hline & 5 & White circle & 6,33 \\
\hline \multirow[t]{2}{*}{ Eyelids color } & 79 & Black & 100 \\
\hline & & Kedness & 0 \\
\hline \multirow[t]{3}{*}{ Ear hair color } & 76 & White & 96,20 \\
\hline & 3 & Brown & 3,79 \\
\hline & & Black & 0 \\
\hline \multirow[t]{2}{*}{ Ear black circle } & 78 & Black & 98,73 \\
\hline & 1 & No black circle & 1,27 \\
\hline \multirow[t]{3}{*}{ Wattle } & & Long & 1,49 \\
\hline & 37 & Medium & 46,84 \\
\hline & 42 & Small & 53,16 \\
\hline \multirow[t]{3}{*}{ Horn } & 1 & Forward & 1,26 \\
\hline & 75 & Upward & 94,94 \\
\hline & 3 & backwards & 3,79 \\
\hline \multirow[t]{2}{*}{ Tail hair } & 77 & Black & 97,47 \\
\hline & 2 & White/panjut & 2,53 \\
\hline \multirow[t]{2}{*}{ Hump } & 0 & Yes & 0 \\
\hline & 79 & No & 100 \\
\hline
\end{tabular}


Based on the results in Table 1 and 2, there were several deviant characters and were considered defective. For example a. There were spots on the body $(2.53 \%)$, b. the white tail feathers (panjut) $(2.53 \%)$, c. no back line $(2.53 \%)$, d. the body color border with the buttocks color was not clear $(1.26 \%)$, e. circular white color on the lips (males $=5.00 \%$ and females $=6,33 \%)$, f. the color of the fur was brown on the ears $(3.79 \%)$, g. Long wattle $(1.67 \%)$ was common in bulls, but generally wattle in medium-sized on male of Bali cattle, $\mathrm{h}$. There was a small hump (males $=3,33 \%$ ). The occurrence of characteristic deviations in cattle such as the appearance of spotted in Bali cattle could be caused by gene mutations [11]. The spotted character in Bali cattle appears at an adult age, while at a young age there was no spotted character. In contrast to the character of the white tail feathers that could be detected from a newborn age. The spotted and panjut characters were immediately removed (selection) and they were not given the opportunity to produce.

Some other deviant characters such as no back line, body color boundaries on the legs were not clear, body color limits on the buttocks color and others were caused by the genes controlling these traits experiencing mutations or due to the presence of genes from other cattle breeds from the ancestors [11]. The existence of a crossbreeding program for Bali cattle with other breeds of cattle could be one of the reasons for the occurrence of undesirable traits in Bali cattle [15]. This possibility could occur uncontrolled spread of Bali cattle breeds, resulting in crosses with other breeds. However, for some of these traits, they were still given the opportunity to produce and were not considered defective as the spotted character and white tail feathers.

Generally, the results of this study showed that the qualitative characteristics of Bali cattle have met the standard of SNI 7651-4:2017. It means that the Bali Breeding Center applied a good breeding program to maintain the specific qualitative character of Bali cattle.

\section{Conclusion}

Qualitative traits in Bali cattle have a good dominant percentage on the typical character of Bali cattle. The percentage of deviant and defective characters in Bali cattle is very small. The qualitative trait selection program was carried out with the age standards prevailing in the community, such as spotted and white tail traits being removed, while other deviant traits were ignored.

\section{References}

1. T. Saili, IOP Conf. Ser.: Earth Environ. Sci. 465012004 (2020)

2. S. Baco, R. Malaka, M. Hatta. IOP Conf. Ser.: Earth Environ. Sci. 492012101 (2020)

3. S. Rahayu, Berkala Penelitian Hayati, 20, 28-35 (2014)

4. M. Purwanti, H. Harry, Jurnal Penyuluhan Pertanian, 1 (2006)

5. K. Amiano, W. Busono, S. Maylinda, TERNAK TROPIKA (Journal of Tropical Animal Production), 21, 39-43 (2020)

6. M. Bahary, Perbedaan Sifat Kualitatif dan Kuantitatif Sapi Bali Tidak Bertanduk dengan Sapi Bali Bertanduk, Undergraduate Thesis, Universitas Hasanuddin Makassar, Indonesia (2017)

7. H. Hikmawaty, A. Gunawan, R. Noor, Jakaria, Jurnal Ilmu Produksi dan Teknologi Hasil Peternakan, 2, 231-237 (2014)

8. H. Martojo, Penyebaran Sapi Bali pada Masa Lampau. Analisis Manfaat dan Risiko Hasil Rekayasa Genetik dalam aspek: Produktivitas, perlindungan dan keanekaan 
hewan. Pusat Antar Universitas Bioteknologi (Institut Pertanian Bogor, Bogor, Indonesia, 1995)

9. A. Supriyantono, O. Yoku, T. Widayati, I. Sumpe, in Prosiding Seminar Nasional Teknologi Peternakan dan Veteriner, pp. $42-46$ (2014)

10. W. Hardjosubroto, Aplikasi pemuliabiakan ternak di lapangan (PT Grasindo Jakarta, Jakarta, Indonesia, 1994)

11. R. Setiaji, S. Prastowo, D. Prasetiyo, N. Widyas, IOP Conf. Ser.: Earth Environ. Sci. 372012032 (2019)

12. Z. Zulkharnaim, S. Baco, L. Rahim, M. Yusuf, Hasanuddin, J Anim Sci, 2,70-75 (2020)

13. K. Mohamad, M. Olsson, G. Andersson, B. Purwantara, H. Van Tol, H. Rodriguez-Martinez, B. Colenbrander, J. Lenstra, Reproduction in domestic animals, 47, 18-20 (2012)

14. B. Purwantara, R. Noor, G. Andersson, H. Rodriguez-Martinez, Reproduction in domestic animals, 47, 2-6 (2012)

15. R.J.W. Setiyabudi : Evaluasi Tren Fenotipik Dan Genetik Sapi Bali Di Balai Pembibitan Ternak Unggul Dan Hijauan Pakan Ternak Denpasar, Master Thesis, Institut Pertanian Bogor, Bogor, Indonesia (2016) 